\title{
Analysis of government bonds and prediction of their development after the pandemic caused by COVID-19
}

\author{
Petr Suler ${ }^{1, *}$ and Vaclav Polan ${ }^{1}$ \\ ${ }^{1}$ Institute of Technology and Business, School of Expertness and Valuation, Okruzni 517/10, 37001 \\ Ceske Budejovice, Czech Republic
}

\begin{abstract}
This paper describes the current state of the government bond market and predicts the future development of government bond yields using the yield curve to bond maturity, spot yield curve, credit rating and simple prediction. The ongoing economic crisis caused by the COVID-19 pandemic is changing the lives of many people. In order for each individual country to help its households, prevent mass job lay-offs and high mortality, their fiscal budget deficits are growing to unexpected heights. The aim of this paper is to analyse government bonds as one of the tools that can help both the state and individual households at this time. Government bond yields are analysed and compared with other countries based on the development of government bonds using credit ratings, yield curves to maturity, spot yield curves and simple historical development of government bonds from the previous economic crisis in 2008. Based on the results, we conclude that countries severely affected by the COVID-19 pandemic and subsequent mortality, such as Italy, have a relatively stable yield. In contrast, for countries such as the Czech Republic and South Korea, yields to maturity at both ends are relatively declining. Keywords: government bond market, prediction, economic crisis, households, yield curve, credit rating
\end{abstract}

\section{Introduction}

The world is in crisis, businesses are closing, employees are being laid off. Neighbouring countries are facing record unemployment, and Austria in particular had an unemployment rate of $12.2 \%$ in the first quarter of 2020 . These numbers are frightening, and after years of economic abundance comes a great wake-up call. This is the highest unemployment rate in Austria since the war. The state of emergency affects restaurants, shops, hotels, accommodation facilities, mass events and more. The economy has slowed down, the number of construction orders is declining, engineering is running out of material and there are no customers for transport and supply industries. Statistics already indicate this, and the steps of individual companies confirm that the time is probably approaching when other countries will encounter similarly high record unemployment. What will be the

\footnotetext{
* Corresponding author: petr.suler@.cez.cz
} 
government's measures? Is it possible to predict the development of the economy for when this situation ceases? How will this situation affect the country, businesses, and the citizens themselves? Can individual subjects mitigate the effects of this crisis and deal with these conditions?

The first to react should be the national government, and each one chose their own approach. The Czech Republic predicts a deficit approaching 300 billion CZK. This is the largest deficit in history. And it must be added that this may not be the final number. What will be the next steps and how will the individual countries differ from each other? Is it possible to predict how much will the support of companies and self-employed individuals decrease or increase? We can find financial instruments that the government will use to respond to this situation.

Prediction of economic development in times of crisis is important. Many companies have expected a crisis and are now activating their crisis plans. However, it can be assumed that few expected such a large-scale crisis. At the time of writing, financial institutions are suspending loans and models estimating the bankruptcy of individual entities and the institutions themselves are sounding the alarm. The importance of predicting the crisis and the development of the economy after its decline became apparent in 2008, when we encountered an economic crisis. The consequences of these failures are far-reaching and affect not only the company itself but also affect all of its stakeholders and participants [12].

Bonds are a type of financial derivative that can help mitigate these effects. In a way, it is a win-win type of tool, where citizens and successful businesses themselves can take part in economic recovery [3]. In view of the development of the situation after 2008, the development of government bonds in recent years and the individual financial steps that governments are taking in the fight against coronavirus, it will be important to predict their development after the COVID-19 crisis has subsided.

Can the Czech Republic and other countries be expected to issue new government bonds? Is it possible to predict that the interest rate and yield of these issued government bonds will increase? Will countries that face fewer financial issues due to COVID-19 than others offer higher interest rates than countries such as Italy or Spain? The aim of this paper will be to analyse the future development of the price and yield of government bonds in areas with significantly differing mortality caused by COVID-19 and thus predict the development of the market after COVID-19.

\section{Literary research}

The recent global financial crisis caused by the COVID-19 pandemic is weakening households, businesses, and the government at the same time. There are only few who can profit from this crisis. The largest companies in the world have lost around $30 \%$ of their value and now they have a long way to go. Berkshire Hathaway Inc. fell from $\$ 340,000$ per share to $\$ 240,000$, agricultural and food company Seaboard Corporation from $\$ 4,000$ per share to $\$ 2,600$ per share and the third most valuable company on the stock exchange, NVR, Inc., even fell from $\$ 4,000$ per share to $\$ 2,000$ per share. Similar figures can be found after the crisis in 2008. Stock markets fell by $50 \%$ because of non-standard mortgages and a slight recession was observed all over the world. These changes, which one does not always expect, cause disintegration and bankruptcy of many households. Every crisis is an opportunity for education, and households must address how to maintain finances and, if necessary, invest them. In contrast, the government must address how to reduce the newly created deficit and where to obtain funding for the necessary investments. Harvey et al. [4] deals with this topic and addresses what opportunities the government has and how they can affect individual households. 
According to Akgun et al. [5], the government has the following options. First of all, the government can increase the tax burden and thus get its investment back. Therefore, if the government supports businesses, their employees or individual entrepreneurs and gives them an injection in the form of forgiveness of certain expenses, or pays a part of their expenses itself, one way to get these funds back will be to increase the tax burden. What businesses and people gain by this help will later be lost. The second option are reforms. According to Madsen, Archard and Thorvaldsen [6], the world is developing mainly technologically, and governments are not reacting quickly enough. Thanks to sometimes too lengthy procedures or rough solutions, companies are forced to slow down their growth. The third option offered to the government is the restructuring of their ministries and stateowned businesses. Especially at a time when unemployment is low, the government is keeping the people the private sector would need for themselves. The government has the opportunity to take these steps, and each one of these steps would help the state treasury. The fourth and, according to Engel [7], most preferred option, is the issuance of government bonds. Robyianto [8] sees government bonds as a certain guarantee for the state and a guarantee for households. Nevertheless, according to Pilar and Helena [9], markets must be regulated to avoid undesirable fluctuations.

According to He, Krishnamurthy and Milbradt [10], bonds have shown us their stability and are a security in the financial market. In general, according to Huong [11], it can be assumed that the size of the economy is positively related to the size of the government bond market. Countries must therefore focus on strengthening the economy itself before strengthening the government bond market. Strong economies predict stable bonds. Nevertheless, a bond may not always be the most appropriate solution and it also poses risks that investors are not aware of. Some companies go bankrupt, others fight for survival, and of course the government bond market is affected by this [12-15]. On the other hand, there is the opinion of Ammer et al. [16], who prefers bonds even at a time when the market is going up. His view is based on the simple statement that bonds in every household's portfolio are important simply because when the market goes down, they are a lever that reduces portfolio loss. Yes, the opposite is also true, as the market goes up, they slow down portfolio growth. Arribas et al. [17] considers knowledge of diversification to be the basis of every successful investor. On the S\&P 500, we can see that when stocks lose value, bonds tend to gain it. We can even find that a portfolio composed of a certain amount of bonds and stocks can outperform the stock index. Bonds lose much less than stocks and can make a profit for the investor even with lower volatility. According to Ammer [16], investors are looking for ways to find foreign bonds at lower yields, as confirmed, for example, by research on USA bonds. At the same time, Blommestein [18] adds that it is necessary to consider all risks and monitor, for example, the monetary policy of a country that significantly affects bond yields. Thus, for households or businesses that deal with future financial stability after each financial crisis, bonds may seem like a suitable type of investment. But can we somehow predict the value of bonds in individual countries in the future, what kind of yield the investor will have, or whether there is a risk of losing finances?

Bonds and their development after several financial crises will serve as a suitable example. Harvey et al. [4] defined these following crises as "Black Monday" (1987), the Gulf War (1998), the Asian Crisis (1998), the Technology Bubble (2000-2002), the World Global Crisis (2007-2009), the first European crisis (2010) and the second European crisis (2011). Based on data from these crises, we can predict the price of government bonds after the COVID-19 crisis.

Vukovic, Hanic and Hanic [19] deals with the question of whether and what effect the crisis has on the financial market. It is important to note that financial markets are experiencing great volatility in times of crisis, and it remains there for some time even after 
the crisis is gradually receding. Investors should take this information into account and hold or sell their bonds accordingly. However, it is not possible to generalize and firmly determine whether it is more appropriate to hold long-term or short-term bonds in a crisis. The value of bonds is determined by many factors, the most important of which are the economic and political stability of the country. According to McKay and Peters [20], various methods can be used to arrive at the answer to how the yields of government bonds of various compared countries will differ after COVID-19. Specifically, for example, by calculating the yield curve from yields to maturity, by calculating the coupon yield curve, the spot yield curve, the rating, the annuity yield curve and many others. Choudhry [21] adds that the markets are not always completely perfect and therefore each method can offer us slightly different results. And even though in times of crisis it is a bit more difficult to predict the development of bonds, according to Martin and Ross [22], the development of bonds with longer maturities can aid us with the prediction.

\section{Data and methods}

First of all, we will compare the development of bonds in three areas. We will look at the development of bonds where COVID-19 hit the most, i.e. Italy, then a moderately affected country, i.e. the Czech Republic, and one of the least affected countries, South Korea. We selected the aforementioned countries according to mortality per 100,000 inhabitants.

To get the most accurate results, we will approach this in 5 different ways. We first predict the development and yield of government bonds according to the yield curve from yields to maturity, then according to the spot yield curve and finally, we use less scientific methods, namely prediction according to credit rating and simple prediction according to the development of government bonds after the 2008 crisis. We will compare the results of these methods with each other and determine the development of government bonds.

We will obtain the data we need from the indices of the rating agencies S\&P Global Ratings, Moody's, and Fitch Ratings, and according to current data on world stock exchanges. We will also base our calculations on national markets. We will need to find out the country's rating, the market price of the bond, the annual coupon payment, the nominal value of the bond, the yield to maturity and the number of years to maturity and the spot interest rate. According to this data, we will calculate everything determined above.

We will analyse bonds with maturities of 1 year, 2 years, 3 years, 4 years, 5 years, 6 years, 7 years, 8 years, 9 years, and 10 years. In the case of South Korea, we will only use a period of 1-5 years until maturity. To obtain the desired results, we will proceed as follows.

\subsection{Prediction of the yield curve from yields to maturity}

Yield to maturity is the rate at which the present value of any future income from a bond equals its current price. Therefore, the following applies to coupon bonds:

$$
P_{T R}=\frac{C}{1+r_{D S}}+\cdots+\frac{C}{\left(1+r_{D S}\right)^{n}}+\frac{N H}{\left(1+r_{D S}\right)^{n}}
$$

$\mathrm{P}_{\mathrm{TR}}$ - market price of bond,

$\mathrm{C}$ - annual interest payment,

$\mathrm{r}_{\mathrm{DS}}-$ yield to maturity,

$\mathrm{n}$ - number of years,

$\mathrm{NH}$ - nominal value of bond. 


\subsection{Prediction according to the spot yield curve}

It is important to proceed year by year to calculate the spot yield curve. First, we calculate the spot interest rate for the first year. We then insert it into the next formula and calculate the spot interest rate for the second year. Afterwards, we use this interest rate again and keep repeating the same procedure.

$$
P_{1}=\frac{C_{1}+N H}{1+r_{0.1}} ; P_{2}=\frac{C_{2}}{1+r_{0.1}}+\frac{C_{2}+N H}{\left(1+r_{0.2}\right)^{2}} ; \ldots
$$

$\mathrm{P}_{\mathrm{n}}$ - bond price for the given year,

$\mathrm{C}_{\mathrm{n}}$ - annual interest payment,

$\mathrm{r}_{\mathrm{x}, \mathrm{y}}$ - yield to maturity for period,

$\mathrm{NH}$ - nominal value of bond.

\subsection{Simple prediction of bond development according to rating}

We base our prediction from the simple knowledge that the better the rating, the lower the expected yield.

\subsection{Simple prediction of bond development according to the values of bonds during the crisis of 2008}

We base our prediction on the known yield rates of two-year government bonds for the period from $8 / 2008$ to $7 / 2009$, we create a yield curve and compare them with the selected countries.

\section{Results}

As already described, in this paper we will focus on three different areas. We will look at the development of bonds where COVID-19 hit the hardest, i.e. Italy, then we will continue with the Czech Republic, which is ranked somewhere in the middle regarding the mortality caused by COVID-19, and finally move on to the country that can be considered an example of how to cope with this pandemic, South Korea. We will analyse each country separately and apply several different methods to the obtained data. Finally, we will use simple methods of comparison with the development of two-year government bonds during the economic crisis in 2008. The prediction of government bond yields according to yields to maturity and according to the spot yield curve will be among the most appropriate methods.

\subsection{Prediction of government bond yields in the Czech Republic}

When monitoring yield calculations from the world's leading agencies, we usually get a yield curve using yield to maturity. But in order to have our results as accurate as possible, I also chose to calculate the spot yield curve. This curve is more accurate, and we obtain it by calculating the spot interest rate for the previous year from the selected formula each time and gradually adding it to the calculation of the following years. 


\subsubsection{Prediction of government bond yields according to yields to maturity and according to spot interest rate}

Table 1 presents the base data for determining the yield and spot curve as of May 5th, 2020. We also see these results in the following charts and compare them with the previous period. We can see from the results for the Czech Republic that the yield decreased significantly compared to the previous year. The results suggest that the Czech Republic's bonds are by no means attractive to investors and are declining. We can observe a smaller difference in multi-year bonds, but even here the yield decreased.

Table 1. Base data for determining the yield and spot curve as of May 5th, 2020

\begin{tabular}{|r|r|r|r|c|}
\hline Sale price & Yield to maturity in \% & Spot interest rate in\% & Coupon & Maturity in years \\
\hline 104.11 & $-0.35 \%$ & $-0.35 \%$ & 3.75 & 1 \\
\hline 107.22 & $0.23 \%$ & $0.24 \%$ & 3.85 & 2 \\
\hline 113.16 & $0.29 \%$ & $0.30 \%$ & 4.7 & 3 \\
\hline 100.20 & $0.40 \%$ & $0.40 \%$ & 0.45 & 4 \\
\hline 125.73 & $0.48 \%$ & $0.50 \%$ & 5.7 & 5 \\
\hline 109.29 & $0.81 \%$ & $0.84 \%$ & 2.4 & 6 \\
\hline 101.02 & $0.85 \%$ & $0.86 \%$ & 1 & 7 \\
\hline 95.04 & $0.90 \%$ & $0.90 \%$ & 0.25 & 8 \\
\hline 113.10 & $0.97 \%$ & $1.01 \%$ & 2.5 & 9 \\
\hline 116.00 & $1.06 \%$ & $1.22 \%$ & 2.75 & 10 \\
\hline
\end{tabular}

Source: Own processing. 2019.

Table 2 presents the base data for determining the yield and spot curve as of May 7 ,

Table 2. Base data for determining the yield and spot curve as of May 7, 2019

\begin{tabular}{|r|r|r|r|c|}
\hline Sale price & Yield to maturity in \% & Spot interest rate in\% & Coupon & Maturity in years \\
\hline 102.01 & $1.70 \%$ & $1.70 \%$ & 3.75 & 1 \\
\hline 104.05 & $1.77 \%$ & $1.77 \%$ & 3.85 & 2 \\
\hline 109.00 & $1.60 \%$ & $1.60 \%$ & 4.7 & 3 \\
\hline 95.39 & $1.65 \%$ & $1.66 \%$ & 0.45 & 4 \\
\hline 118.81 & $1.74 \%$ & $1.75 \%$ & 5.7 & 5 \\
\hline 104.44 & $1.62 \%$ & $1.61 \%$ & 2.4 & 6 \\
\hline 94.67 & $1.82 \%$ & $1.82 \%$ & 1 & 7 \\
\hline 88.20 & $1.85 \%$ & $1.85 \%$ & 0.25 & 8 \\
\hline 105.34 & $1.85 \%$ & $1.86 \%$ & 2.5 & 9 \\
\hline 107.99 & $1.87 \%$ & $2.09 \%$ & 2.75 & 10 \\
\hline
\end{tabular}

Source: Own processing.

The yield curve according to yields to maturity is shown in Figure 1 for comparison between the dates of May 7, 2020 and May 7, 2019. 


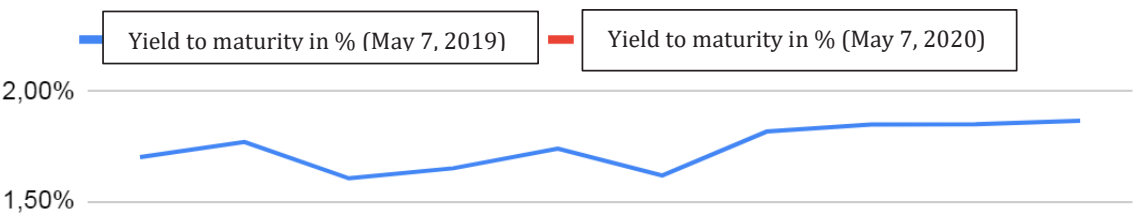

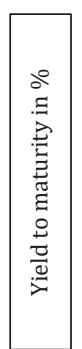

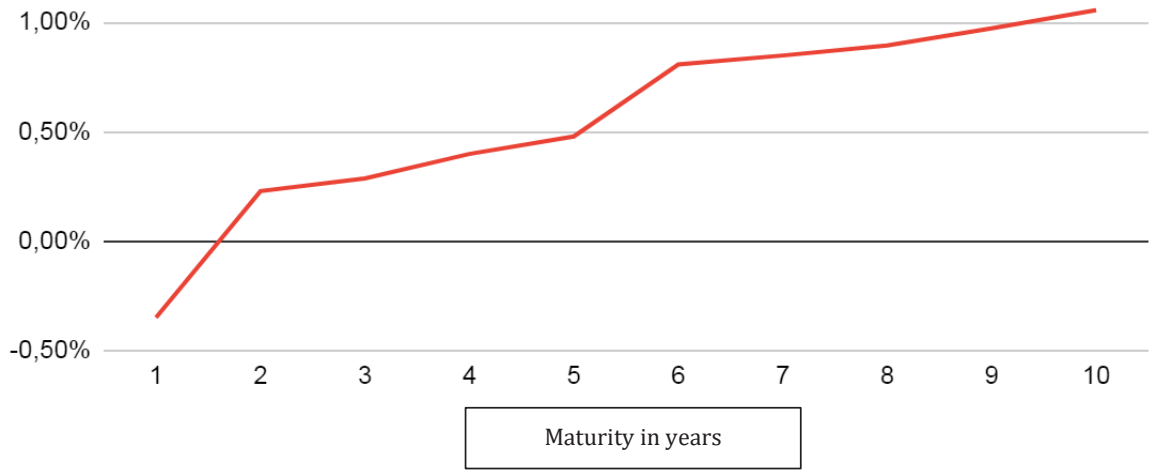

Fig. 1. Yield curve according to yields to maturity

Source: Own processing.

The spot yield curve is shown in Figure 2 with a comparison between May 7, 2020 and May 7, 2019.

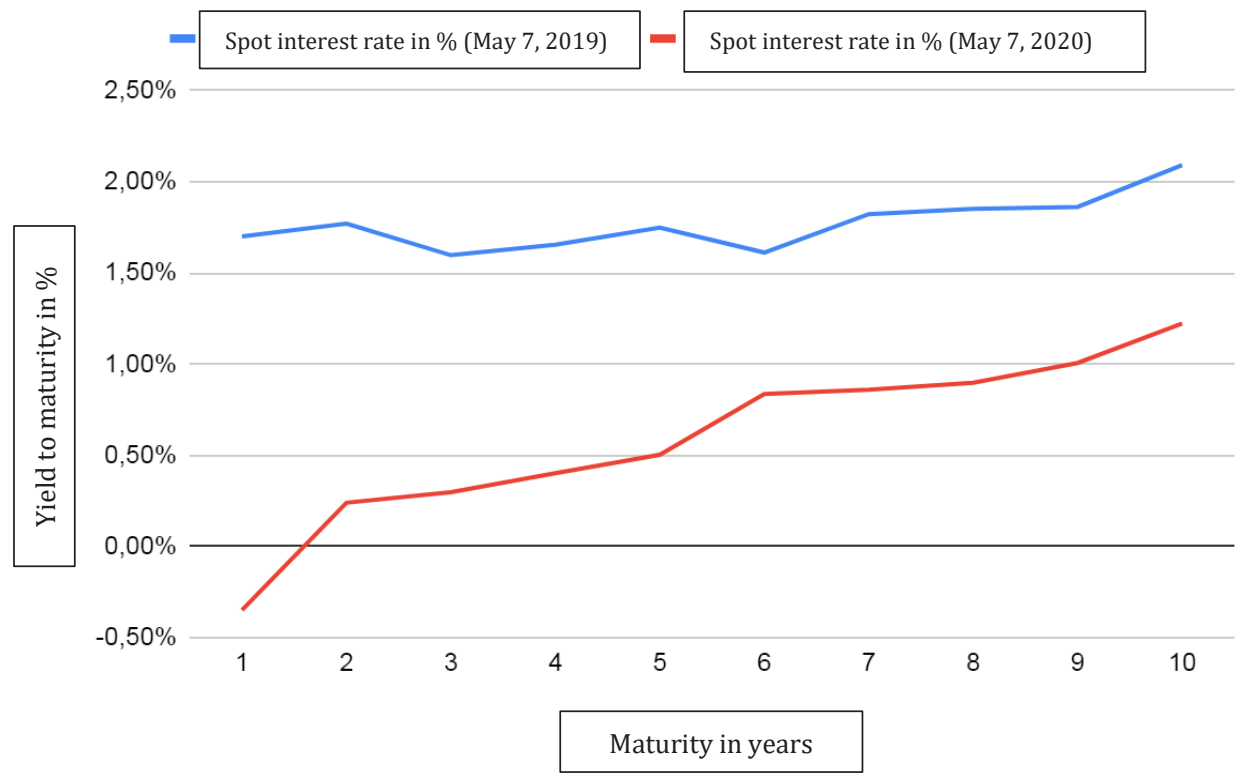

Fig. 2. Spot yield curve

Source: Own processing. 


\subsubsection{Simple prediction of bond development according to rating}

According to well-known statements, we know that a country's rating depends on the rate of inflation, the political and economic situation in the country and many other conditions. The rating of the Czech Republic according to selected rating agencies is shown in Table 3. The rating agencies view the Czech Republic as trustworthy; it is a stabilized environment, and a potential investor can thus perceive the bonds as more or less risk-free. On the other hand, no high returns can be expected, and if we base our investment only on the rating, we would assume a stable, but still quite low return.

Table 3. Rating assessment of the Czech Republic according to selected credit rating agencies

\begin{tabular}{|c|c|}
\hline Rating agency & Rating \\
\hline Standard \& Poor's & AA- \\
\hline Moody's Investors Service & Aa3 \\
\hline Fitch Ratings & AA- \\
\hline
\end{tabular}

Source: Own processing, according to www.worldgovernmentbonds.com.

\subsection{Prediction of government bond yields in Italy}

\subsubsection{Prediction of government bond yields according to yields to maturity and according to the spot interest rate}

According to the results below, we can see that the short-term maturity yield is growing compared to the previous year. On the other hand, with increasing maturity, the yield decreases compared to 2019. These results suggest a minimal effect caused by COVID-19. While the Czech Republic has the status of a stable country for the time being and yields are falling proportionally from shorter to longer maturities, we see slightly different results in Italy. In Italy, we see that the country is currently more attractive to investors, both in the short and long term. In particular, short-term yield with a maturity of 1 to 3 years is more interesting than in the previous year. Given the management of the current pandemic, it can be assumed that we will see a similar yield in Italy in the near future. 2020 .

Table 4 presents the base data for determining the yield and spot curve as of May 7 ,

Table 4. Base data for determining the yield and spot curve as of May 7, 2020

\begin{tabular}{|r|r|r|r|c|}
\hline Sale price & Yield to maturity in \% & Spot interest rate in \% & Coupon & Maturity in years \\
\hline 99.79 & $0.21 \%$ & $0.21 \%$ & 0 & 1 \\
\hline 100.42 & $0.79 \%$ & $0.79 \%$ & 1 & 2 \\
\hline 98.94 & $0.96 \%$ & $0.96 \%$ & 0.6 & 3 \\
\hline 101.83 & $1.28 \%$ & $1.30 \%$ & 1.75 & 4 \\
\hline 101.73 & $1.49 \%$ & $1.51 \%$ & 1.85 & 5 \\
\hline 102.78 & $1.61 \%$ & $1.63 \%$ & 2.1 & 6 \\
\hline 94.75 & $1.65 \%$ & $1.66 \%$ & 0.85 & 7 \\
\hline 106.96 & $1.86 \%$ & $1.91 \%$ & 2.8 & 8 \\
\hline 108.80 & $1.93 \%$ & $1.98 \%$ & 3 & 9 \\
\hline
\end{tabular}




\begin{tabular}{|r|r|r|r|c|}
\hline 94.74 & $1.93 \%$ & $2.18 \%$ & 1.35 & 10 \\
\hline
\end{tabular}

Source: Own processing.

Table 5 presents the base data for determining the yield and spot curves as of May 7 , 2019 .

Table 5. Base data for determining the yield and spot curve as of May 7, 2019

\begin{tabular}{|r|r|r|r|c|}
\hline Sale price & Yield to maturity in \% & Spot interest rate in \% & Coupon & Maturity in years \\
\hline 99.95 & $0.06 \%$ & $0.06 \%$ & 0 & 1 \\
\hline 100.92 & $0.54 \%$ & $0.54 \%$ & 1 & 2 \\
\hline 98.81 & $1.01 \%$ & $1.01 \%$ & 0.6 & 3 \\
\hline 101.64 & $1.33 \%$ & $1.36 \%$ & 1.75 & 4 \\
\hline 100.88 & $1.67 \%$ & $1.69 \%$ & 1.85 & 5 \\
\hline 101.05 & $1.91 \%$ & $1.95 \%$ & 2.1 & 6 \\
\hline 92.32 & $2.04 \%$ & $2.06 \%$ & 0.85 & 7 \\
\hline 104.08 & $2.24 \%$ & $2.31 \%$ & 2.8 & 8 \\
\hline 105.66 & $2.30 \%$ & $2.37 \%$ & 3 & 9 \\
\hline 89.03 & $2.61 \%$ & $2.96 \%$ & 1.35 & 10 \\
\hline
\end{tabular}

Source: Own processing.

The yield curve according to yields to maturity is shown in Figure 3 with a comparison between May 7, 2020 and May 7, 2019.
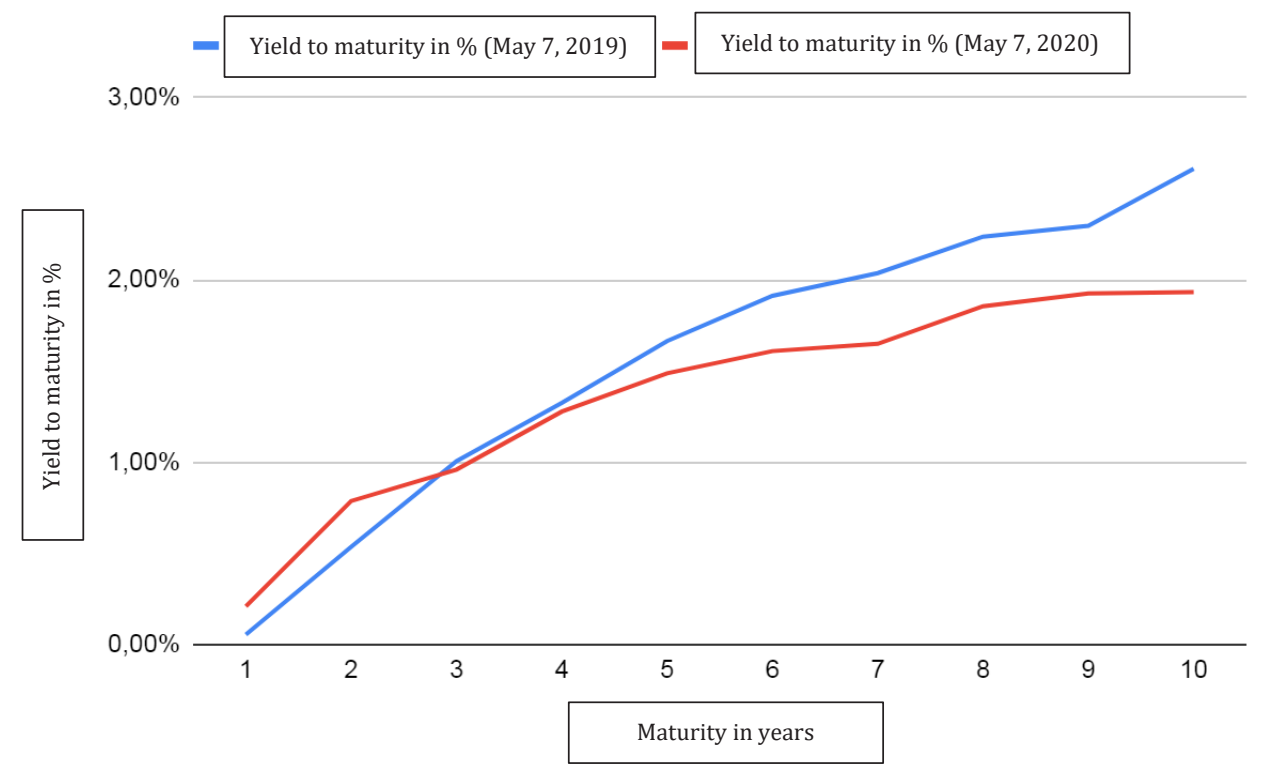

Fig. 3. Yield curve according to yields to maturity

Source: Own processing.

The spot yield curve is shown in Figure 4 with a comparison between May 7, 2020 and May 7, 2019. 


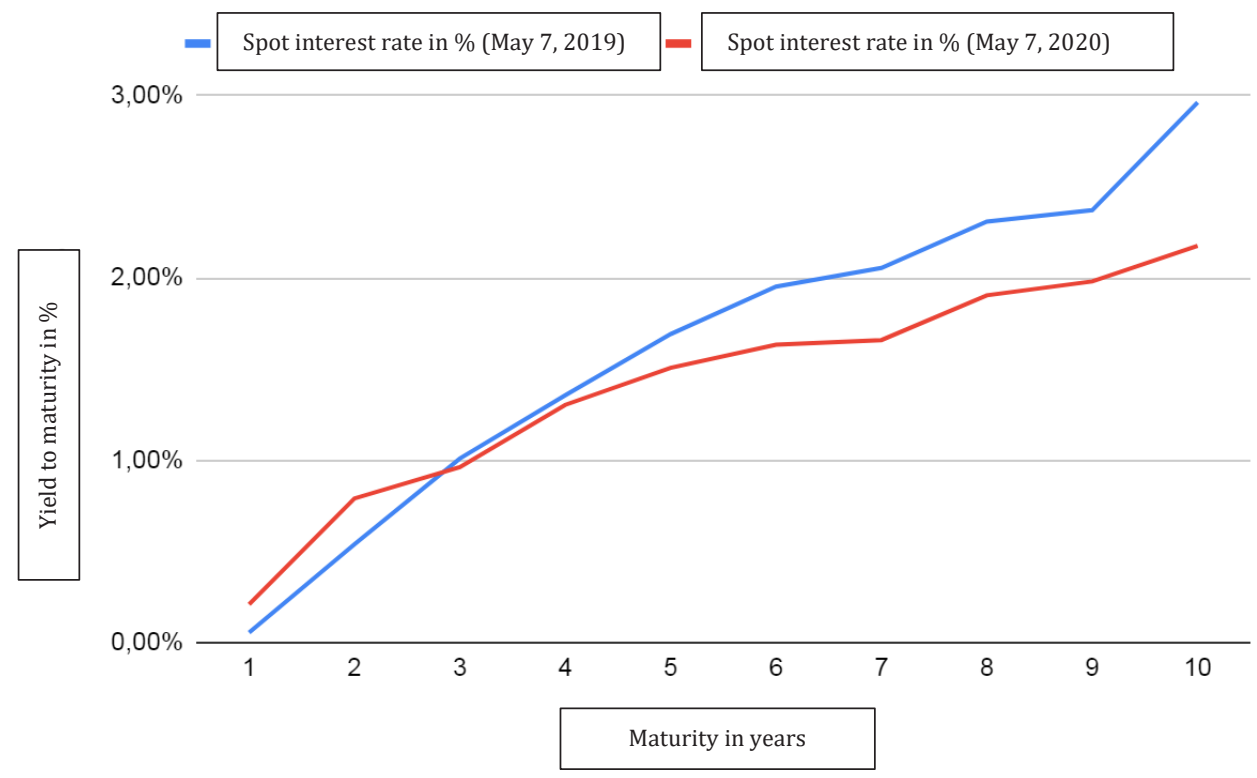

Fig. 4. Spot yield curve

Source: Own processing.

\subsubsection{Simple prediction of bond development according to rating}

Italy's rating confirms that this country is one of the most affected by the current pandemic. The rating of Italy according to selected rating agencies is shown in Table 6. Credit rating agencies still value this country as a safe opportunity for investment, therefore not speculative, but at the last possible level. Nevertheless, if we look at this assessment, it is still interesting for the investor. It is not yet a speculative investment, but relatively high and safe yields can still be expected.

Table 6. Rating of Italy according to selected credit rating agencies

\begin{tabular}{|c|c|}
\hline Rating agency & Rating \\
\hline Standard \& Poor's & BBB \\
\hline Moody's Investors Service & Baa3 \\
\hline Fitch Ratings & BBB- \\
\hline
\end{tabular}

Source: Own processing, according to www.worldgovernmentbonds.com.

\subsection{Prediction of government bond yields in South Korea}

4.3.1. Prediction of government bond yields according to yields to maturity and according to the spot interest rate

South Korea is often considered the model country that managed the current pandemic in the best way possible. These views are also reflected in the yields of their bonds, which fell compared to the previous year, so we can expect early stability of the country. On the other 
hand, South Korea still offers interesting returns starting from the first year to maturity and, for example, for the first year to maturity, it is still more attractive to investors than Italy and the Czech Republic, despite the aforementioned decline. South Korea offers a stable yield that deviates by a maximum of 0.5 percentage points over 5 years and there is no indication that this yield should change in the future. 2020 .

Table 7 presents the base data for determining the yield and spot curves as of May 7 ,

Table 7. Base data for determining the yield and spot curves as of May 7, 2020

\begin{tabular}{|r|r|r|r|c|}
\hline \multicolumn{1}{|c|}{ Sale price } & Yield to maturity & Spot interest rate & Coupon & Maturity in years \\
\hline 101.46 & $0.77 \%$ & $0.77 \%$ & 2.25 & 1 \\
\hline 101.46 & $0.89 \%$ & $0.89 \%$ & 1.625 & 2 \\
\hline 100.88 & $0.95 \%$ & $0.95 \%$ & 1.25 & 3 \\
\hline 102.94 & $1.12 \%$ & $1.14 \%$ & 1.875 & 4 \\
\hline 101.38 & $1.21 \%$ & $1.22 \%$ & 1.5 & 5 \\
\hline
\end{tabular}

Source: Own processing.

Table 8 presents the base data for determining the yield and spot curves as of May 7 , 2019.

Table 8. Base data for determining the yield and spot curves as of May 7, 2019.

\begin{tabular}{|r|r|r|r|c|}
\hline \multicolumn{1}{|c|}{ Sale price } & Yield to maturity & Spot interest rate & \multicolumn{1}{c|}{ Coupon } & Maturity in years \\
\hline 100.53 & $1.72 \%$ & $1.72 \%$ & 2.25 & 1 \\
\hline 99.79 & $1.73 \%$ & $1.73 \%$ & 1.625 & 2 \\
\hline 98.65 & $1.72 \%$ & $1.71 \%$ & 1.25 & 3 \\
\hline 101.57 & $1.47 \%$ & $1.48 \%$ & 1.875 & 4 \\
\hline 98.80 & $1.75 \%$ & $1.76 \%$ & 1.5 & 5 \\
\hline
\end{tabular}

Source: Own processing.

The yield curve according to yields to maturity is shown in Figure 5 with a comparison between May 7, 2020 and May 7, 2019. 


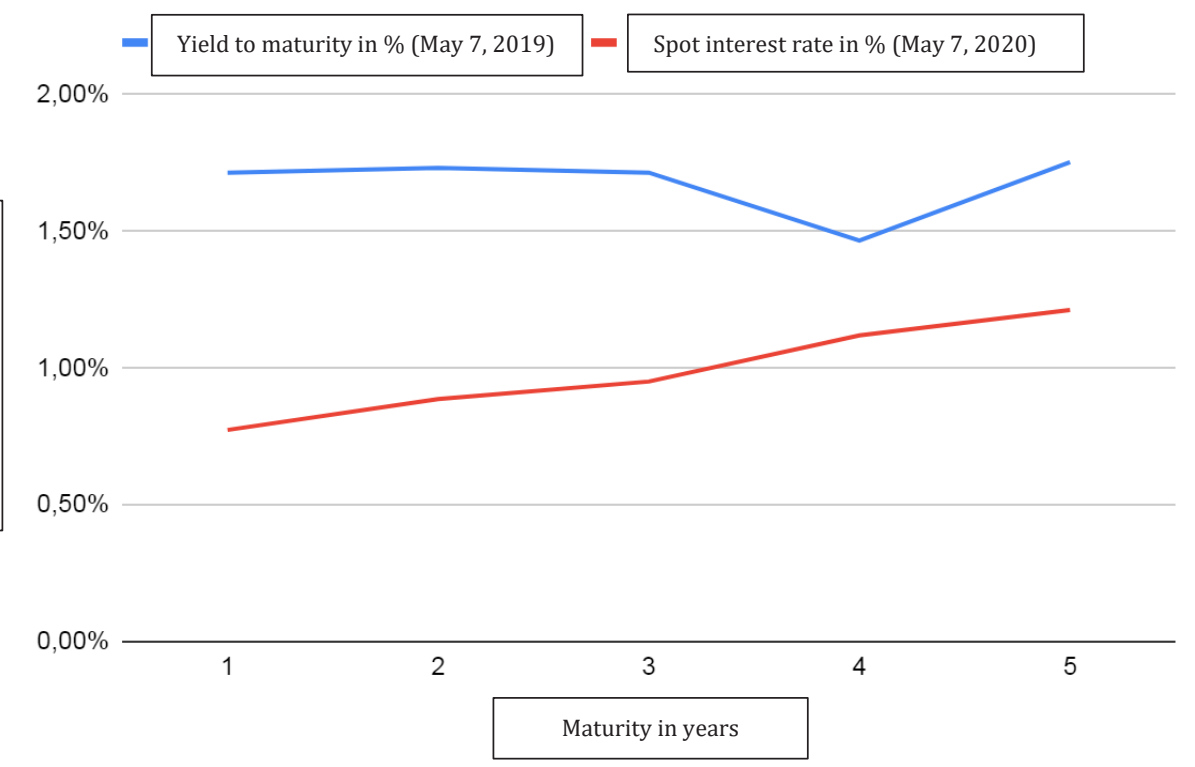

Fig. 5. Yield curve according to yields to maturity

Source: Own processing.

The spot yield curve is shown in Figure 6 with a comparison between May 7, 2020 and May 7, 2019.
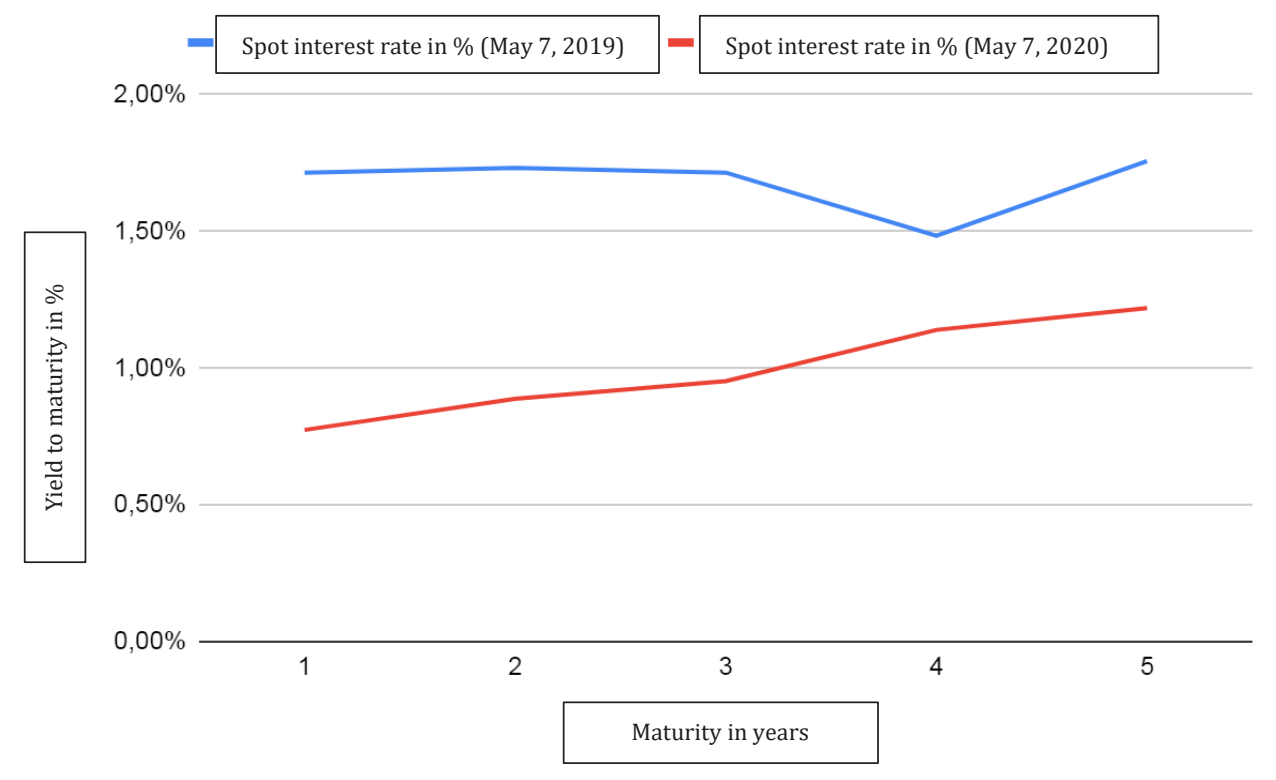

Fig. 6. Spot yield curve

Source: Own processing. 


\subsubsection{Simple prediction of bond development according to rating}

The stability of the country and the successful fight against COVID-19 are also confirmed by rating agencies, which place this country in the category of bonds with an investment opportunity and a relatively strong position. South Korea's credit rating according to selected rating agencies is shown in Table 9. Based on this rating, investors cannot expect high returns, on the other hand, according to the rating it is a politically and economically stable country and investors' finances are relatively safe here.

Table 9. Rating assessment of South Korea according to selected rating agencies

\begin{tabular}{|c|c|}
\hline Rating agency & Rating \\
\hline Standard \& Poor's & AA \\
\hline Moody's Investors Service & Aa2 \\
\hline Fitch Ratings & AA- \\
\hline
\end{tabular}

Source: Own processing, according to www.worldgovernmentbonds.com.

\subsection{Simple prediction of government bonds and international comparison according to the development of bonds after the economic crisis in 2008}

In order to predict the development of government bonds after the COVID-19 pandemic subsides, we compared their development in the period of August 2008 to July 2009, i.e. the beginning and subsequent gradual easing of the economic crisis. An international comparison of the development of 2-year government bonds for the period of 08/2008 to 07/2009 is shown in Figure 7. If we assume that the lower the yield, the stronger the rating and the stability of the country, we see from the chart below that Italy's bonds performed the best and did not record yield growth even once. So, the results slightly contradict the previous ones, where we see that Italy is managing the current crisis the worst out of the selected countries. Nevertheless, if this data on two-year government bonds during the economic crisis at the turn of 2008 and 2009 should lend us help in predicting their current development, the chart shows that after surviving the initial boom, all 3 of these countries stabilized relatively quickly and the same can be expected now. Spot yield curves or forward yield curves, for example, will be a more suitable form of predicting the future value of government bonds. 


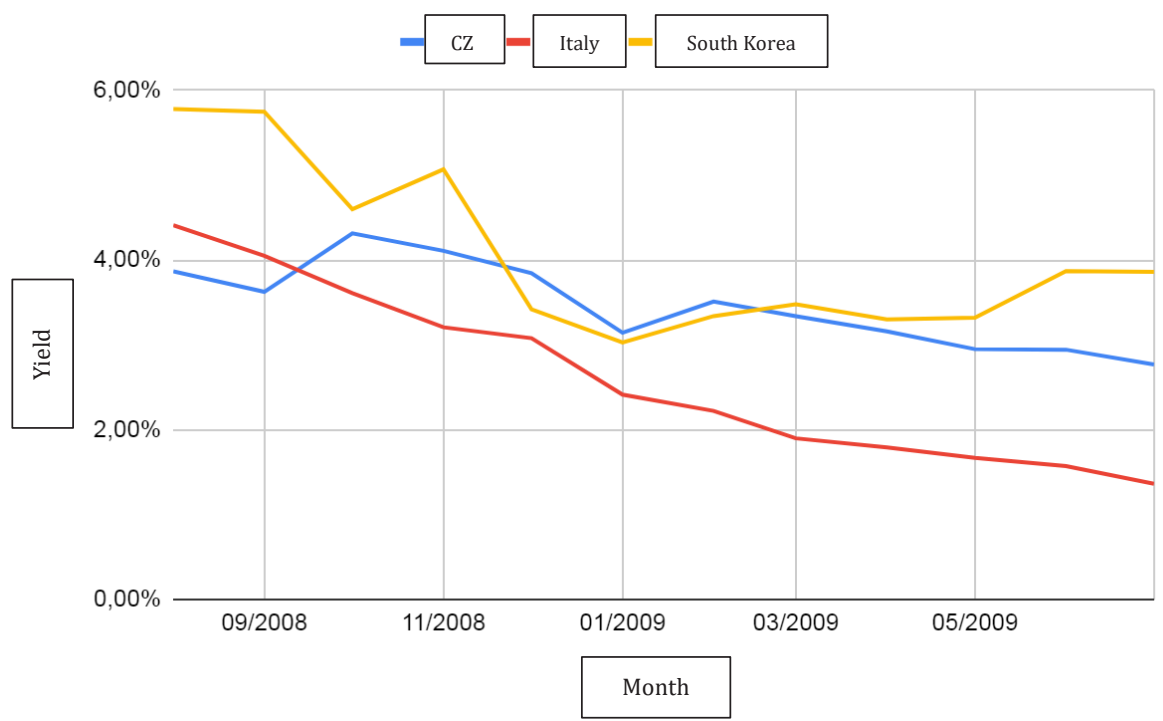

Fig. 7. International comparison of the development of 2-year government bonds for the period of 08/2008-07/2009

Source: Own processing.

\section{Conclusion}

This paper describes the current state of the government bond market and predicts the future development of government bond yields using the yield curve to maturity, spot yield curve, rating and simple prediction. The yield curve itself is a unique tool that can predict the development of the bond market for the following period. If we consider the normal rising shape of the yield curve, its slope is important. A steeper yield curve suggests that short-term yields are lower and money market investments are less profitable than longterm bond investments. In conclusion, we can certainly refute the hypothesis that the countries hit hardest by the COVID-19 pandemic and with the highest mortality per 100,000 inhabitants are also the most affected ones when it comes to government bonds in terms of rising yields. Based on the results, we find that the hardest hit countries, such as Italy, have a relatively stable yield. In contrast, in countries such as the Czech Republic and South Korea, yields to maturity at both ends are declining relatively.

Bond securities are referred to as a conservative type of investment and are popular mainly because they provide investors with a reasonable return on the investment in comparison with their low riskiness. Yield curves to maturity and spot yield curves show us that even though a year ago Italy was the strongest of the countries observed and thus had the strongest yields, the current situation has changed everything and Italy is the one that offers the highest yields of the countries analysed.

The results above are also confirmed by the credit rating of the selected countries. The better the rating, the lower the yields can be expected. Looking back at the results on the current rating, it is clear that the least stable country is Italy, which should therefore also offer the highest yields. Nevertheless, these are still the most attractive and, in a way, still relatively safe bonds. 


\section{References}

1. A.P. Balcerzak, T. Kliestik, D. Streimikiene, L. Smrcka, Non-parametric approach to measuring the efficiency of banking sectors in European Union countries. Acta Polytechnica Hungarica, 14(7), 51-70 (2017)

2. Z. Virglerova, L. Homolka, L. Smrcka, K. Lazanyi, T. Kliestik, Key determinants of the quality of business environment of SMEs in the Czech Republic. $E \& M$ Ekonomie a Management, 20(2), 87-101 (2017)

3. A. Kasych, S. Kizhemiakina, M. Vochozka, O. Romanenko, V. Glukkhova, A world model of social entrepreneurship in a crisis. Journal of Entrepreneurship Education, 22(Special Issue), 1-6 (2019)

4. C.R. Harvey, E. Hoyle, S. Rattray, M.Sargaison, D. Taylor, O. Van Hemert, The best of strategies for the worst of times: Can portfolios be crisis proofed? Journal of Portfolio Management, 45(5), 7-28 (2019)

5. O. Akgun, D. Bartolini, B. Cournede, The capacity of governments to raise taxes. OECD Economics Department Working Papers, No. 1407, OECD Publishing [online], Available at: https://www.oecd-ilibrary.org/economics/the-capacity-ofgovernments-to-raise-taxes_6bee2df9-en

6. S. S. Madsen, S. Archard, S. Thorvaldsen, How different national strategies of implementing digital technology can affect teacher educators. Nordic Journal of Digital Literacy, 13(04), 7-23 (2019)

7. C. Engel, Safe U.S. assets and U.S. capital flows. Journal of International Money and Finance, 102 (2020)

8. R. Robiyanto, Gold VS bond: What is the safe haven for the Indonesian and Malaysian capital market? Gadjah Mada International Journal of Business, 20(3), 277-302 (2018)

9. A. Pilar, C. Helena, European Government bond market contagion in turbulent times. Czech Journal of Economics and Finance (Finance a uver), 66(3), 263-276 (2016)

10. Z. He, A. Krishnamurthy, K. Milbradt. What makes US government bonds safe assets? American Economic Review, 106(5), 519-523 (2016)

11. T.T.T. Huong, The determinants of government bond market development in ASEAN+3. International Journal of Science and Research, 9(3), 1284-1289 (2020)

12. V. Stehel, J. Horak, M. Vochozka, Prediction of institutional sector development and analysis of enterprises active in agriculture. E+M Ekonomie a Management, 22(4), 103-118 (2019)

13. J. Horak, J. Vrbka, P. Suler, Support vector machine methods and artificial neural networks used for the development of bankruptcy prediction models and their comparison. Journal of Risk and Financial Management, 13(3), (2020)

14. T. Klieštik, K. Valaskova, G. Lazaroiu, M. Kovacova, J. Vrbka, Remaining financially healthy and competitive: The role of financial predictors. Journal of Competitiveness, 12(1), 74-92 (2020)

15. T. Kliestik, J. Vrbka, Z. Rowland, Bankruptcy prediction in Visegrad group countries using multiple discriminant analysis. Equilibrium-Quarterly Journal of Economics and Economic Policy, 13(3), 569-593 (2018)

16. J. Ammer, S. Claessens, A. Tabova, C. Wroblewski, Home country interest rates and international investment in U.S. bonds. Journal of International Money and Finance, 95, 212-227 (2019)

17. I. Arribas, M.D. Espinós-Vañó, F. García, R. Tamošiūnienė, Negative screening and sustainable portfolio diversification. Entrepreneurship and Sustainability Issues, 6(4), 1566-1586 (2019) 
18. H. Blommestein, Impact of regulatory changes on government bond market liquidity. Journal of Financial Regulation and Compliance, 25(3), 307-317 (2017)

19. D.B. Vukovic, E. Hanic, H. Hanic, Financial integration in the European Union The impact of the crisis on the bond market. Equilibrium, 12(2), 195-210 (2017)

20. D.R. Mckay, D.A. Peters, Bond basics and the yield curve. Plastic Surgery, 27(1), 83-85 (2018)

21. M. Choudhry, The yield curve. The Moorad Choudhry Anthology, 272-343 (2018)

22. I.W.R. Martin, S.A. Ross, Notes on the yield curve. Journal of Financial Economics, 134(3), 689-702 (2019) 